\title{
Rare and new Laboulbeniales from Poland. VII
}

\author{
TOMASZ MAJEWSKI \\ Institute of Botany, Polish Academy of Sciences, 00-478 Warszawa, \\ al. Ujazdowskie 4, Poland
}

\begin{abstract}
Majewski T., Rare and new Laboulbeniales from Poland. VII. Acta Mycol. 17: 53-62, 1981.

This publication gives descriptions of four new species: Dipodomyces phloeocharidis sp. n. on Phloeocharis subtilissima, Rickia pachylaelapis sp. n. on Pachylaelaps holothyroides, and Rickia ptiliidarum sp. n. on Nannoptilium sp. There are also the localities of six other species new for Poland,
\end{abstract}

\section{Chitonomyces ensiferus Spegazzini}

On Laccophilus hyalinus (Deg.) (Coleoptera, Dytiscidae): Brzuze Duże (Ostrolęka voivodeship), in a shallow bay of the Narew river, close to the village, 4.7 .1979 (TM. 2241, 2246, 2247). Fig. 1b.

Single specimens of this fungus have been found on the distal segments of left tarsi of hosts. They are in accord with short diagnose and drawing of Chitonomyces ensiferus (S pegazzini 1915). The length of two well-preserved specimens was 115 and $125 \mu \mathrm{m}$, respectively, while the perithecia were $88-90 \times 21-30 \mu \mathrm{m}$. This fungus seems not to have been hitherto given from stands other than locus classicus.

\section{Chitonomyces italicus Spegazzini}

On Laccophilus hyalinus (Deg.): Brzuze Duże (as with Ch. ensiferus) (TM. 2242, 2248, 2249). Fig. 1a.

Nine specimens of this species have been taken out of left tarsi of hosts, caught together with the hosts of Ch. ensiferus. They differ from the Spegazzini type (1915) in the same way as the specimens described in Bavaria by Scheloske (1969). They are longer and 


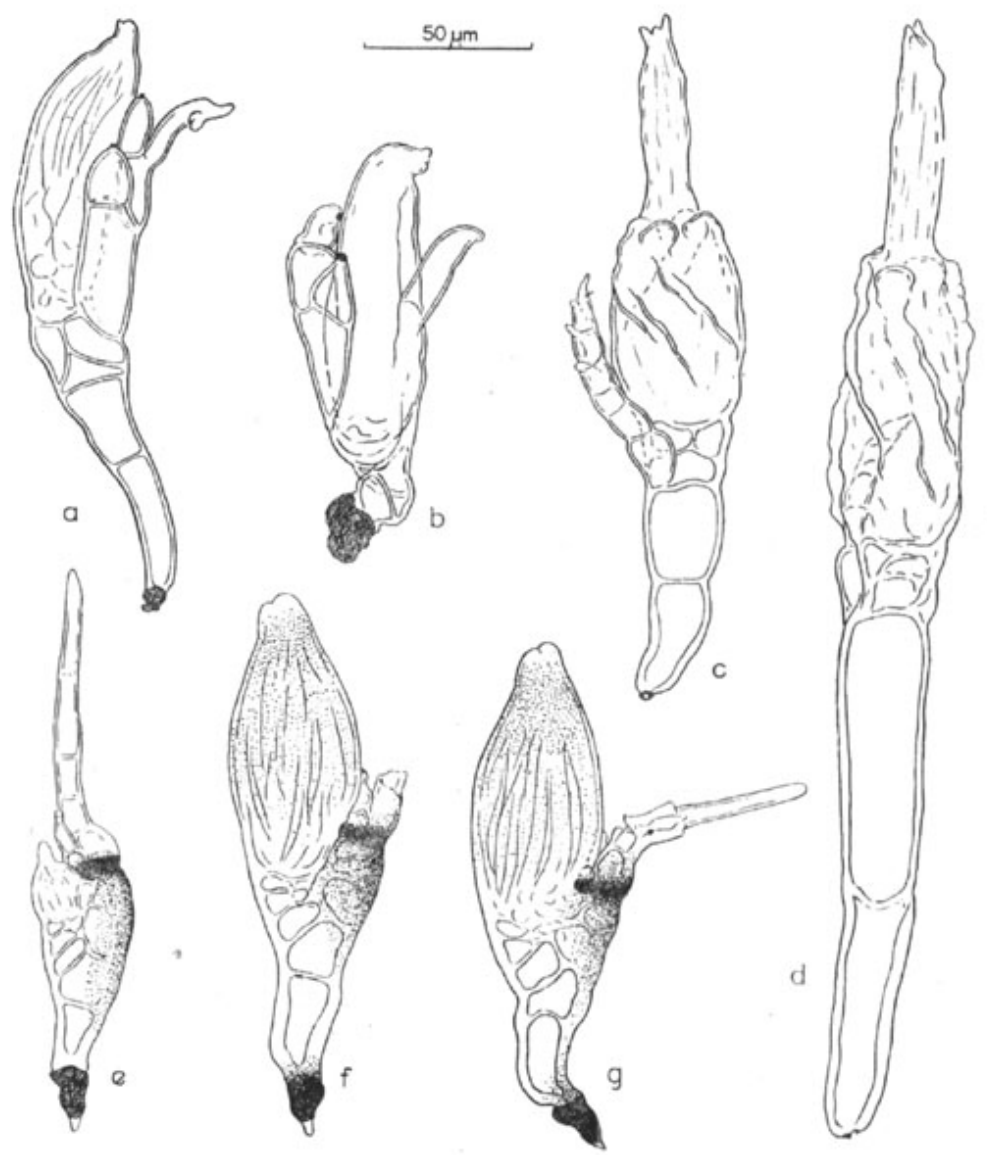

Fig. 1. a-Chitonomyces italicus Speg. on Laccophilus hyalinus, Brzuze Duże; $b$-Chitonomyces ensiferus Speg. on Laccophilus hyalinus, Brzuze Duże; $c, d-$ Stigmatomyces purpureus Thaxter on Scatella stagnalis, Pomiechowo; e, $f, g-$ Laboulbenia biondii Rossi et Cesari Rossi on Orestia aubei ssp. arcuata, Bereżki.

slimmer, their length being 140-180 $\mu \mathrm{m}$. Nearly the whole thallus, except for the basal cell, is amber brown.

This species is known from Italy (S pega z z in i 1915), the Federal Republic of Germany (S c heloske 1969), also from China ( $\mathrm{T}$ h a x ter 1926) and Japan (S ug i y m a 1977), where, however, a more stout and darker form was found, more corresponding to the $\mathrm{S} \mathrm{p} \mathrm{e} \mathrm{g} \mathrm{a} \mathrm{z} \mathrm{z} \mathrm{in} \mathrm{i's}$ type. 
Dimeromyces longitarsi Thaxter

On Longitarsus luridus (Scopoli) (Col., Chrysomelidae): Bieszczady Mts., Wetlina (Krosno voivodeship), in a decaying haystack in the meadow north of the village, at the foot of the Wetlina Upland pasture, about $700 \mathrm{~m}$ above sea level, 19.6.1978 (TM. 1905).

A number of the fungus' males and females were found on the elytra of the host. They fully correspond to the desoription and pictures by Thaxter (1924: 361-362, pl. 5: 129-131). This rare species is known from the United States and Trinidad ( $\mathrm{Th}$ a $\mathrm{xt}$ e $\mathrm{r}$ 1. c.) as well as France (B a la z u c 1975), and most probably also from Algeria if Dimeromyces bordei Maire is identical with it.

\section{Dipodomyces phloeocharidis sp. $\mathrm{n}$.}

Thallus luteolus. Receptaculum primarium ex duabus cellulis constans; cellula basalis elongata, cellula subbasalis compressa. Cellula subbasalis appendicem antheridialem et paulo lateraliter cellulam pedunculi perithecii separat. Axis appendicis antheridialis ex sex vel septem cellulis una supra aliam positis, quae praeter basalem elongatae sunt, in parte superiore ramosa, antheridia elongata terminalia habet. Cellula pedunculi perithecii elongata, cellularum basalium regio angustior. Perithecium asymmetricum, margo eius externa convexa, ad apicem angustatur, cum labiis tribus acutis.

Longitudo tota ad apicem perithecii $110-155 \mu \mathrm{m}$, perithecia $55-95 \times$ $\times 23-38 \mu \mathrm{m}$, appendices ad $100 \mu \mathrm{m}$.

Yellowish. Primary receptacle consisting of two cells: the basal cell elongated, the subbasal flattened. The subbasal cell bears distally the antheridial appendage and somewhat laterally the stalk-cell of the perithecium. Axis of the appendage consisting of six or seven superposed cells; all of which, with exception of the basal cell, are elongated. The fourth and next cells producing distally on the inner side the few celled branches which are one or two times branched, with elongated terminal antheridia. The stalk-cell of the perithecium 2-3-times longer than the width, somewhat contracted at the base. The basal cell region broader, the secondary stalk-cell and the basal cells inflated. The perithecium stout, the outer margin convex, the inner nearly straight; the neck tapering distally to the tip with three longer and pointed and one shorter lips.

Total length to the tip of the perithecium 110-155 $\mu \mathrm{m}$, perithecium 55-95 $\times 23-38 \mu \mathrm{m}$, antheridial appendage up to $100 \mu \mathrm{m}$.

On Phloeocharis subtilissima Mann. (Col., Staphylinidae): Pomiechówek near Nowy Dwór Mazowiecki (Warszawa voivodeship), under the bark of dry, standing Pinus sylvestris in a pine wood close to the Wkra 


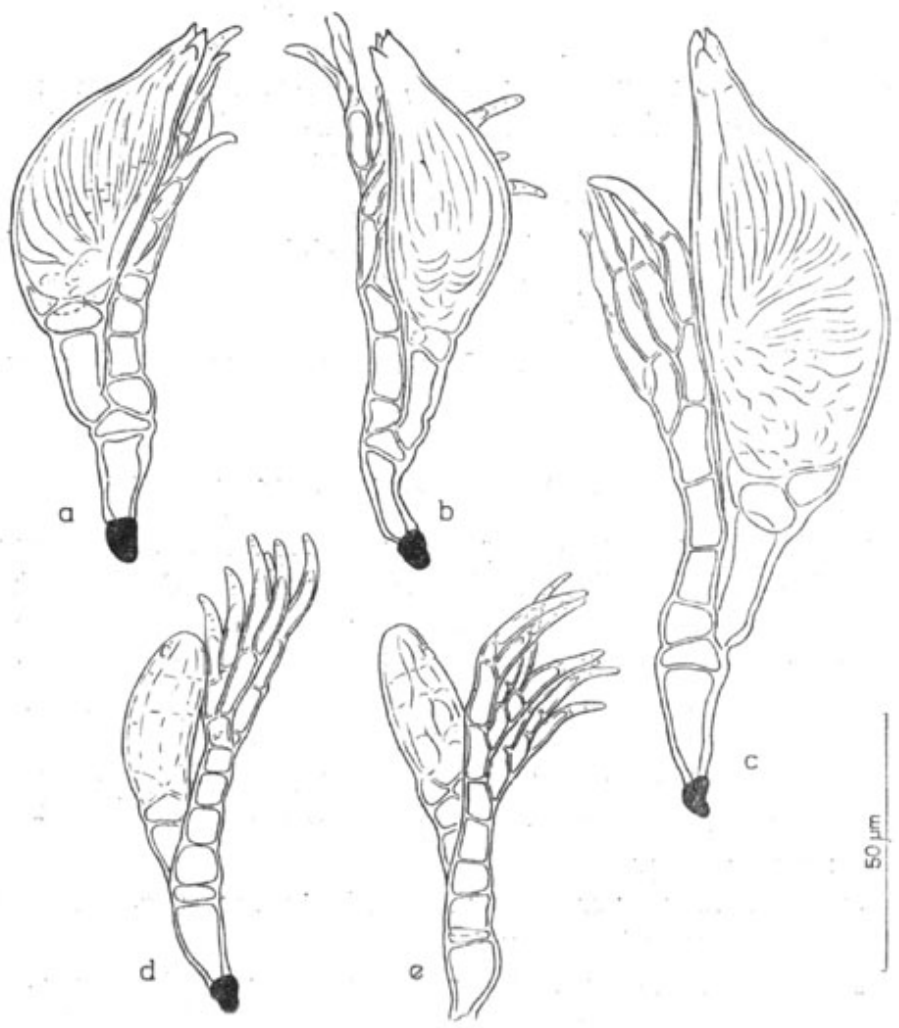

Fig. 2. Dipodomyces phleocharidis sp. n. on Phloeocharis subtilissima, Pomiechówek; $a$-holotype, b-e-isotypes

river, 3.7.1977 (TM. 1689, 1690), 27.7.1977 (TM. 1698), 3.8.1977 (TM. 1699), 21.8.1977 (TM. 1700, 1701-holotype), leg. T. M a jewski. Fig. 2. This fungus is at first sight clearly different from the only hitherto known representative of the genus Dipodomyces, D. monstruosus Thaxter (Thaxter 1931: 267, pl. 37: 19-23), described from Africa on a representative of the family Colydiidae. Much simpler is the construction of its receptacle, which does not form lateral outgrowth which occur at D. monstruosus, and consists of fewer cells of more regular structure. These traits should be taken into account in the new, expanded diagnosis of the genus Dipodomyces. On the other hand, the structure of the perithecium and antheridial appendage is similar at both species. I owe gratitude for these suggestions to Dr. I. T a vares, who was so 
kind as to make a comparison between my species with $\mathrm{T}$ haxter's type of the genus Dipodomyces.

Numerous specimens of the new species occurred on the elytra, abdomen, lower thorax and legs of the hosts.

\section{Laboulbenia biondii Rossi et Cesari Rossi}

On Orestia aubei Allard ssp. arcuata Miller (Col., Chrysomelidae): Bieszczady Mts., Bereżki (Krosno voivodeship), in the bedding of Alnus incana shrub, on the Bystry creek, about $650 \mathrm{~m}$ above sea level, 11.9.1972 (TM. 1112). Fig. 1 e-g.

The author collected about thirty specimens of this species on the elytra of one beetle. This fungus was recently described in Italy ( $\mathrm{R}$ o s $\mathrm{s}$ i, Cesari Rossi 1979). The Polish specimens differ from those by slightly smaller size: total length $143-160 \mu \mathrm{m}$, perithecia $73-88 \times 35-40 \mu \mathrm{m}$.

\section{Rickia pachylaelapis sp. $\mathrm{n}$.}

Thallus hyalinus, late ellipticus. Series media plerumque ex quatuor cellulis formata. Series posterior ex quinque vel sex cellulis, quarum una vel duae inferiores duas cellulas appendiculatas separant, cellulae superiores singulas cellula appendiculata habent. Series anterior ex duabus vel tribus cellulis constat, omnes cum singulis vel binis cellulis appendiculatis. Perithecium ovatum, margo eius externa libera. Appendices irregulariter elongatae, interdum ramosae; antheridium plerumque unicum in serie anteriore prope perithecium.

Altitudo tota 75-88 $\times 40-50 \mu \mathrm{m}$, perithecia $38-48 \times 20-28 \mu \mathrm{m}$.

Hyaline, triseriate. The body broadly elliptical in outline, borne on the abruptly distinguished, slightly intruded basal cell. Median series of usually four cells, three of which beside the perithecium, the upper somewhat elongate, the remainings irregularly isodiammetric. The margin cells somewhat radially elongated. The posterior series of five or six cells, separating single appendiculate cells, with the exception of the one or two lower cells with two appendiculate cells. The primary appendage somewhat lateral, lying beside the upper appendiculate cell. The anterior series of two or three cells with one or two appendiculate cells. Appendages irregularly elongated, sometimes ramified, the normal free antheridium usually only one on the anterior side near the perithecium. Perithecium rounded, nearly erect, externally free, with a short neck and truncate apex.

Total dimensions $75-88 \times 40-50 \mu \mathrm{m}$, perithecia $38-48 \times 20-28 \mu \mathrm{m}$.

On Pachylaelaps holothyroides (Leonardi) (Acarina, Pachylaelapidae): 

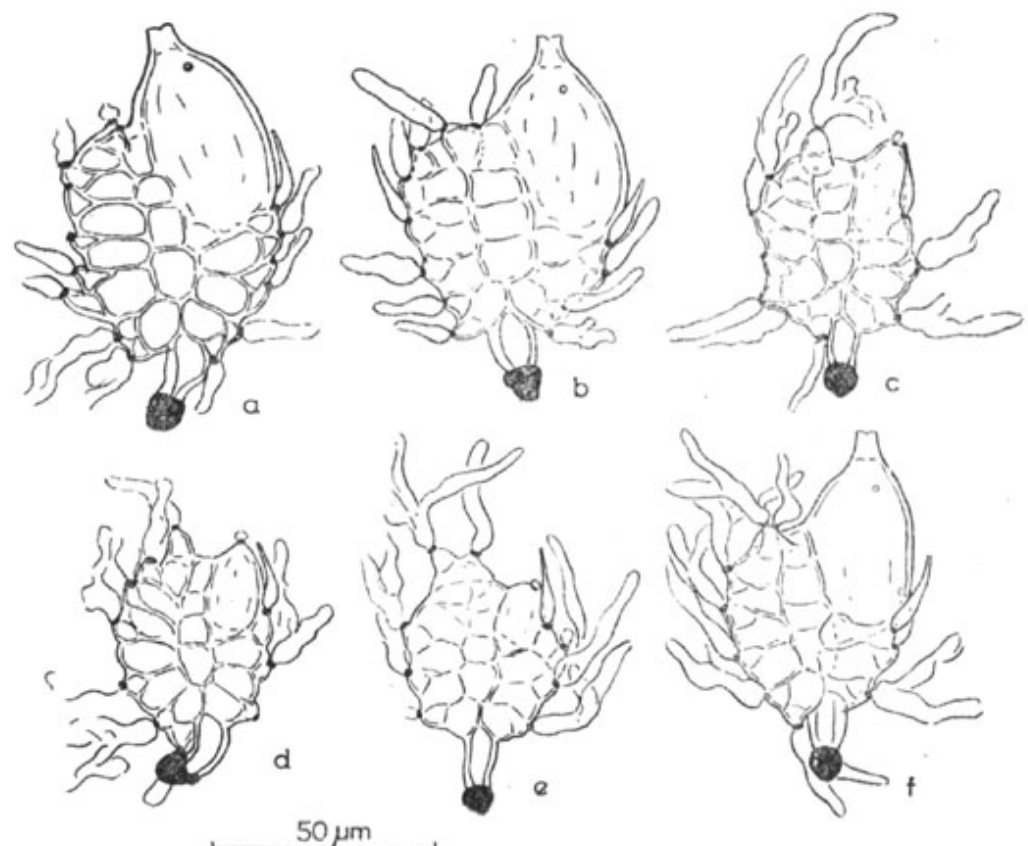

Fig. 3. Rickia pachylaelapis sp. n. on Pachylaelaps holothyroides, Puszczykowo; $a$ - holotype, $b-f-$ isotypes

Puszczykówko near Poznań (Poznań voivodeship), on the worker of Lasius flavus (Fabr.) in a nest under stone in a garden, 20.5.1979 leg. Piotr M i chalski (TM. 2032-2037; 2034-holotype). Fig. 3.

From among the numerous species described hitherto from the genus Rickia, the specimens found most resemble Rickia celaenopsis Th. and $R$. inclinata Th., which are also parasites of Acarina, and have been described from Trinidad ( $\mathrm{Th}$ a $\mathrm{x}$ ter 1926). Rickia celaenopsis differs in its immersed antheridium and only two strongly flattened anterior cells with one appendiculate cell. Rickia inclinata differs also in only two cells in the anterior series, and usually only one appendiculate cell on the posterior series of cells. The marginal cells of the Polish species are not so elongated as these cells of $R$. celaenopsis and $R$. inclinata, and appendages seems to be longer.

More than 30 examined specimens grew on the legs and thorax of one specimen of female mite. They, with their host, had been bleached with lactophenol, so some traits of their structure might have been slightly changed. 


\section{Rickia ptiliidarum sp. $\mathrm{n}$.}

Thallus late fusiformis, luteolus, venter perithecii ferrugineus. Cellula basalis receptaculi minutissima. Series media plerumque ex tribus compressis cellulis formata. Series posterior ex quinque cellulis, cellula infima magna, obtriangulata, cetera minores, superior cum cellula appendiculata libera. Series anterior tantum una cellula cum una cellula appendiculata habet. Perithecium erectum, ovatum, collum rectum et residuum trichogyni nigrum distinctum.

Altitudo tota $63-65 \times 25-28 \mu \mathrm{m}$, perithecia $40-43 \times 15-18 \mu \mathrm{m}$.

Pale yellowish, the venter of the perithecium yellow-brownish. Basal cell of the receptacle very small, indistinct, replaced by the lowest cell of the posterior series. Median series of usually three cells; they are narrow, the two upper lying beside the perithecium, the lower below its base. The posterior series of five cells; the lowest obtriangular, relatively broad, the second connected with the lower on its wholly upper surface, asymmetrically triangular and flattened, the third and fourth
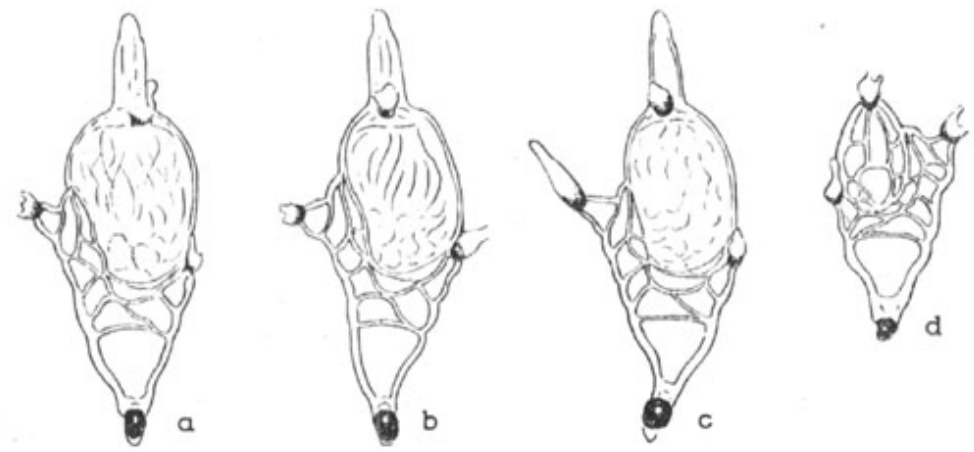

$50 \mu \mathrm{m}$

Fig. 4. Rickia ptiliidarum sp. n. on Nannoptilium sp., Białowieża; $a$-holotype, $b-d-$ isotypes

irregularly isodiammetrical, the upper narrow, separating laterally one respectively large, free appendiculate cell. The anterior series of only one somewhat flattened cell with one appendiculate cell. The perithecium erect, free externally, its body broadly oval, the neck abruptly distinguished, as long as a half of the venter, slightly tapering to the top. The base of the trichogyne persistent, blackened, forms a short appendage. 
Total dimensions $63-65 \times 25-28 \mu \mathrm{m}$, perithecia $40-43 \times 15-18 \mu \mathrm{m}$.

On Nannoptilium sp. (Col., Ptiliidae): Białowieża National Park (Bialystok voivodeship), in horse manure on a road through Querco-Carpinetum in section 369, 22.5.1973 leg. T. M a je w s k i (TM. 1990-holotype, 1993). Fig. 4.

Rickia ptillidarum is the second representative of this genus that is a parasite on beetles from the family Ptiliidae. From the described from Bavaria Rickia nephanis (Scheloske 1969) it differs most clearly, mainly because of different, simpler structure of the receptacle: a reduced basal cell and only one appendiculate cell in the posterior part of the thallus. The thalli of the new species are about twice smaller than those of Rickia nephanis.

Few specimens (four mature and one young) were found by the author on the elytra and pronotum of the host. It is to be assumed that it is a rare fungus, for many other beetles from other stands have been checked without result.

\section{Sphaleromyces lathrobii Thaxter}

On Lathrobium quadratum (Payk.) (Col., Staphylinidae): Giby (Suwałki voivodeship), in Sphagna on the bank of a forest lake in the Tobolinka reservation, 19.8.1978 (TM. 1922-1924).

Numerous specimens of the fungus in various development stages were found on the upper surface of the host's body (pronotum, elytra, abdomen). The are in accord with the description and pictures by Th a x ter (1896: 365-366, pl. 11: 2-5, 19). The species described from North America, found also on Lathrobium quadraturi in Europe, but without more detailed data ( $\mathrm{T}$ h a x t e r 1931, sub Corethromyces lathrobii).

\section{Stigmatomyces purpureus Thaxter}

On Scatella stagnalis (Fall.) (Diptera, Ephydridae): Pomiechowo near Nowy Dwór Mazowiecki (Warszawa voivodeship), on a muddy bank of the Wkra river, 21.8.1974 (TM. 1505-1512); on Scatella sp.: as above (TM. 1513-1514). Fig. 1 c, d.

Numerous specimens found display high variability, similarly to the typical material described by $\mathrm{Th}$ axter (1908). Frequent are specimens relatively stout, with the thallus length $170-220 \mu \mathrm{m}$ and poorly developed ridges (Fig. $1 \mathrm{c}$ ). In the Pomiechowo material, however, specimens were also found, the length of which reached $320 \mu \mathrm{m}$; the were dark coloured, with distinct, strongly protruding ridges (Fig. 1 d). 
Stigmatomyces purpureus was described by $\mathrm{Th}$ a $\mathrm{xte}$ (1908: 302, pl. 46: 30-36) from the United States, later found in Great Britain (B iffen 1909), India (B a tra 1963, sub. S. scatellae), France (H. Dainat, J. Dainat 1973) and Italy (Rossi, Cesari Rossi 1979a). In India, France and Italy only more common specimens were described, with shortened receptacle.

\section{Acknowledgements}

I am very indebted to Dr. S. M a zur, Institute of Forest Protection, Agricultural Academy, Warsaw, for the determination of beetles from the family Staphylinidae; to Doc. Dr. A. Warchalow ski, Institute of Zoology, University of Wroclaw, for determining the representatives of Chrysomelidae; to Doc. Dr. A. Szeptycki, Institute of Systematical and Experimental Zoology, Polish Academy of Sciences, Cracov, for the determination of Nannoptilium; to Dr. J. T. N owa kowski, Institute of Ecology, Polish Academy of Sciences, Dziekanów, for determining of Scatella. Prof. Dr. J. Wiśn ni e w sk i, Institute of Forest Protection, Academy of Agriculture, Poznań, kindly favoured me with infected and determined Pachylaelaps; Mrs. M. K orzy bs k a helped me in translating of Latin diagnoses. I am also indebted to Dr. I. I. T a vares, University of California, for important remarks on the new species of Dipodomyces.

\section{REFERENCES}

B a lazuc J., 1975, Recherches sur les Laboulbéniomycetes. III. Laboulbeniales parasites de Coléoptères Chrysomélides, avec description d'espèces nouvelles. Rev. de Mycol. 39: 189-211.

B at r a S. W. T., 1963, Some Laboulbeniaceae (Ascomycetes) on insects from India and Indonesia. Amer. J. Bot. 50: 986-992. .

Biffen R. H., 1909, First record of two species of Laboulbeniaceae for Britain. Trans. Br. mycol. Soc. 3: 83 ,

D a in a t H., Da in a t J., 1973, Sur dix espèces du genre Stigmatomyces (Laboulbeniales) parasites de Diptères Acalyptérés dans le Sud de la France. Bull. Soc. Mycol. France 89: 337-352.

Rossi W., Cesari Rossi M. G., 1979, Due specie nuove di Laboulbenia (Ascomycetes Laboulbeniales) parassite di Chrysomelidae (Insecta Coleoptera). Natura (Milano) 70: 89-93.

Rossi W., Cesari Rossi M. G., 1979a, Su alcune specie di Stigmatomyces (Ascomycetes Laboulbeniales) parassite di Ditteri italiani. Boll. Mus. Civ. Venezia 30: 13-18.

Scheloske H.-W., 1969, Beiträge zur Biologie, Okologie und Systematik der Laboulbeniales (Ascomycetes) unter besonderer Berücksichtigung des Parasit-Wirt-Verhältnisses. Parasitol. Schr. Reihe 19: 1-176.

Spegazzini C., 1915, Segunda contribución al conocimiento de las Laboulbeniales italianas. An. Mus. Nac. Hist. Nat. Buenos Aires 27: 37-74.

Sugi y a ma K., 1977, Notes on species of the genus Chitonomyces (Laboulbeniomycetes) of Japan. Trans. mycol. Soc. Japan 18: 155-160. 
Thaxter R., 1896, 1908, 1924, 1926, 1931, Contribution towards a monograph of the Laboulbeniaceae. Part I, II, III, IV, V. Mem. Amer. Acad. Arts Sci. 12(3): 187-429, pl. 1-26; 13(6): 217-469, pl. 28-71; 14(5): 309-426, pl. 1-22; 15(4): 427-580, pl. $1-24 ; 16(1): 1-435$, pl, 1-60.

\section{Rzadkie i nowe Laboulbeniales z Polski. VII}

\section{Streszczenie}

Praca zawiera opisy nowych gatunków: Dipodomyces phloeocharidis sp. n. na Phloeocharis subtilissima, Rickia pachylaelapis sp. n. na Pachylaepaps holothyroides (Acarina) i Rickia ptiliidarum sp. n. na Nannoptilium sp. (Col., Ptiliidae). Podano również stanowiska sześciu gatunków nowych dla flory Polski. 